\title{
Mapping of corn phenological stages using NDVI from OLI and MODIS sensors
}

\section{Mapeamento dos estádios fenológicos da cultura do milho utilizando o NDVI derivado dos sensores OLI e MODIS}

\author{
Luan Peroni Venancio ${ }^{1 *}$; Roberto Filgueiras ${ }^{1}$; Fernando França da Cunha ${ }^{2}$; \\ Francisco Charles dos Santos Silva ${ }^{3}$; Robson Argolo dos Santos ${ }^{4}$; \\ Everardo Chartuni Mantovani ${ }^{2}$
}

\begin{abstract}
Highlights:
Images from MODIS and OLI sensors were used. Corn phenology was evaluated through NDVI. Data were validated by model identity testing. NDVI can help identify problems in corn crops.
\end{abstract}

\begin{abstract}
Crop phenology knowledge is relevant to a series of actions related to its management and can be accessed through vegetation indexes. Thus, this study aimed to evaluate the use of the Normalized Difference Vegetation Index (NDVI), from images of OLI and MODIS sensors, to obtain phenological information from corn crops. To this end, we evaluated two corn cropping areas, irrigated by a central pivot, and located western Bahia state, Brazil. These areas were managed with high technology and had no record of biotic and abiotic stresses. NDVI showed a well-defined temporal pattern throughout the corn cycle, with a rapid increase at the beginning, stabilization at intermediate stages, and decreases at the end of the cycle. Excellent fits for polynomial equations were obtained to estimate NDVI as a function of days after sowing (DAS), with $\mathrm{R}^{2}$ values of 0.96 and 0.95 for images of OLI and MODIS sensors, respectively. This demonstrates that both sensors could characterize corn canopy changes over time. NDVI ranges were correlated with the main phenological stages (PE), using the direct relationship between both variables (NDVI and PE) with days after sowing (DAS). For the beginning and end of each phenological stage, NDVI ranges were validated through model identity testing. NDVI proved to be a suitable parameter to assess corn phenology accurately and remotely. Finally, NDVI was also an important tool for detecting biotic and abiotic stresses throughout the crop cycle, and hence for decision making based on corn phenology.
\end{abstract}

Key words: Vegetation index. Satellite images. Remote sensing. Zea mays L.

${ }^{1}$ Pós-Doutorandos do Programa de Pós-Graduação em Engenharia Agrícola, Universidade Federal de Viçosa, UFV, Viçosa, MG, Brasil. E-mail: luan.venancio@ufv.br; betofilgueiras@gmail.com

${ }^{2}$ Profs. Drs., Departamento Engenharia Agrícola, UFV, Viçosa, MG, Brasil. E-mail: fernando.cunha@ufv.br; everardo@ufv.br

3 Dr., Programa de Pós-Graduação em Fitotecnia, UFV, Viçosa, MG, Brasil. E-mail: fcsantossilva-ma@hotmail.com

${ }^{4}$ Discente do Curso de Doutorado do Programa de Pós-Graduação em Engenharia Agrícola, UFV, Viçosa, MG, Brasil. E-mail: argolo.agro@gmail.com

* Author for correspondence 


\section{Resumo}

O conhecimento da fenologia das culturas é relevante para uma série de ações relacionadas ao seu manejo e pode ser acessada por meio de índices de vegetação. Portanto, objetivou-se com este trabalho avaliar o potencial do uso do Índice de Vegetação por Diferença Normalizada (NDVI), calculado a partir de imagens dos sensores OLI e MODIS para obter informações fenológicas da cultura do milho. Para tanto, foram utilizadas duas áreas de cultivo de milho irrigadas por sistema de pivô central na região oeste do estado da Bahia, Brasil. Estas áreas foram manejadas com alta tecnologia e sem registro de ocorrência de estresses bióticos e abióticos. O NDVI apresentou um padrão temporal bem definido ao longo do ciclo de desenvolvimento, com rápido incremento no início do desenvolvimento, estabilização nos estádios intermediários, e decréscimos na parte final do ciclo. Excelentes ajustes para as equações polinomiais foram obtidos para estimar o NDVI em função dos dias após a semeadura (DAS), com R ${ }^{2}$ de 0,96 e 0,95 para as imagens do sensor OLI e MODIS, respectivamente, demonstrando que os sensores são capazes de caracterizar temporalmente as modificações do dossel da cultura do milho ao longo do ciclo. Intervalos de valores de NDVI foram correlacionados com os principais estádios fenológicos (EF) da cultura do milho, utilizando a relação direta de ambas as variáveis (NDVI e EF) com os dias após a semeadura (DAS). Os intervalos de valores de NDVI para o início e final de cada estádio fenológico foram validados através do teste de identidade do modelo, tornando o NDVI uma variável adequada para ser utilizada no acesso a fenologia do milho com precisão de maneira remota. Por fim, esses valores também são uma importante ferramenta para detecção de problemas bióticos e abióticos ao longo do ciclo de cultivo e para tomadas de decisão baseadas na fenologia da cultura.

Palavras-chave: Índice de vegetação. Imagens de satélite. Sensoriamento remoto. Zea mays L.

\section{Introduction}

Knowing crop phenological patterns is relevant for a series of actions, among them accurate identification of biotic and abiotic stresses. If acquired before conservation and management efforts, data on phenological dynamics of ecosystems and agricultural systems could enable prediction of growth and production rates, increasing chances of success of these efforts (Kuplich, Moreira, \& Fontana, 2013). For corn, understanding phenological patterns is crucial for decision making such as defining the ideal time for weed control (Kozlowski, 2002; Kozlowski, Koehler, \& Pitelli, 2009; Rizzard, Silva, \& Vargas, 2006).

Several are ways to identify the beginning and mean length of corn phenological stages. Among them, accumulated degree-days (ADD) have been shown to be the best option (Gadioli, Dourado, García, \& Basanta, 2000; Martins et al., 2017; Tsimba, Edmeades, Millner, \& Kemp, 2013). This method has been recommended for corn since its physiology is highly influenced by temperature
(Cross \& Zuber, 1972; Cutforth \& Shaykewich, 1990; Gadioli et al., 2000). Another way is based on the number of days after sowing (DAS) or after emergence (DAE) (Borges, Von Pinho, \& Pereira, 2009; Forsthofer, Silva, Argenta, Strieder, Suhre, \& Rambo, 2004). However, as stated earlier, such approaches generate less accurate data given the effect of thermal availability on corn growth and development. Besides, it is important to consider the use of vegetation indices (IV), which are calculated using images from orbital sensors. These indices are strongly related to several biophysical parameters of vegetation (Ji \& Peters, 2007). Thus, they can be an alternative to infer crop phenology spatially and temporally.

Dozens of vegetation indexes available in the literature can be used in several vegetation studies, among which is the Normalized Difference Vegetation Index (NDVI) (Rouse, Hass, Schell, \& Deering, 1973). NDVI is one of the most used vegetation indexes (Adole, Dash, \& Atkinson, 2016; Matsushita, Yang, Chen, Onda, \& Qiu, 2007) because it is highly related to several biophysical 
parameters, such as leaf area index (Kross, McNairn, Lapen, Sunohara, \& Champagne, 2015), leaf nitrogen content ( $\mathrm{Li}$ et al., 2014), grain yield (Maresma, Ariza, Martínez, Lloveras, \& MartínezCasasnovas, 2016; Wang, Tao, \& Shi, 2014), among others. Furthermore, after normalization, a large proportion of noise caused by changes in sunlight incidence angle, topography, clouds or shadow, and atmospheric conditions can be canceled (Huete, Justice, \& Leeuwen, 1999; Rouse et al., 1973). Previous studies have shown that crop phenology can be determined by vegetation indexes, with emphasis on the studies by Pan et al. (2015) in wheat and corn and by Zheng, Wu, Zhang and Zeng (2016) in rice.

Orbital sensor images, in turn, allow obtaining information on the spatial-temporal distribution of study variables systematically and even costfree (Khanal, Fulton, \& Shearer, 2017; Kuplich et al., 2013) for large areas (Atzberger, 2013). Among the sensors, Moderate Resolution Imaging Spectroradiometer (MODIS) stands out compared to the others. A series of products are derived from images captured by this sensor, among them MOD09Q1, which contains surface reflectance images in the red (R) and near-infrared (NIR) wavelengths, which are the most indicated and used in vegetation studies (Jensen, 2011). Other features of the MOD09Q1 are 250-m spatial resolution and eight-day temporal resolution (Justice et al., 2002). For corn crops, as well as for other annual crops, which show substantial morphophysiological changes within short time intervals, the availability of images every eight days can be an excellent option for defining phenological patterns.

Another sensor that stands out is the Operational Land Imager (OLI), which is onboard the Landsat 8 satellite. Yet, it has a smaller temporal resolution (16 days) compared to MOD09Q1. On the other hand, it is considered an excellent option in vegetation studies, mainly due to its spatial resolution of 30 meters (Roy et al., 2014; United States Geological Survey [USGS], 2016) that is high compared to that of MOD09Q1 (250 meters). Therefore, studies using this sensor improve spatial detailing of areas of interest. Finally, combining two or more sensors with different temporal and spatial resolutions is relevant, as they may provide complementary information and increase the level of detail in the study area.

Previous studies with both sensors, MODIS and OLI, have shown that crop phenology can be assessed using vegetation indexes (Fontana, Pinto, Junges, \& Bremm, 2015; Jayawardhana \& Chathurange, 2016; Pan et al., 2015; Sakamoto et al., 2005; Zheng et al., 2016). Based on an accurate characterization of crop phenological stages for assertive decision making in the field and potential of satellite images to acquire surface space-time information, this study aimed to evaluate the potential use of the Normalized Difference Vegetation Index (NDVI), calculated from images from the OLI and MODIS sensors, to obtain phenological information from corn crops, and particularly to define the length of each phenological stage based on average NDVI values.

\section{Material and Methods}

\section{Study area}

The present study was carried out using two central pivot areas, which belong to a commercial farm in the city of Serra do Ramalho, in western Bahia state, Brazil (Figure 1). Central pivot area one (P1) has 90 ha arable area and the following central geographical coordinates: $13^{\circ} 13^{\prime} 50.32^{\prime}$ ' S, 43 $42^{\circ}$ 35.83" W (Datum SIRGAS 2000). Central pivot area two (P2) has 66 ha and the following central geographical coordinates: $13^{\circ} 12^{\prime} 42.12^{\prime} \mathrm{S}, 43^{\circ} 43^{\prime}$ $0.50^{\prime}$ W. Average altitude of the areas is about 444 m. According to Köppen's climate classification (Alvares, Stape, Sentelhas, Moraes Gonçalves, \& Sparovek, 2013), the local climate is Aw type, which stands for a tropical climate, with a rainy season in summers and drought in winters, and a normal annual rainfall of $797.5 \mathrm{~mm}$, according to 
the Instituto Nacional de Meteorologia (INMET) (2018). The local soil is classified as Yellow Latosol (Santos et al., 2011).

\section{Field data}

We used field data of corn crop (Zea mays L.) provided by the IRRIGER (http://irriger.com.br/ $\mathrm{pt}-\mathrm{BR} /$ ). This company is responsible for irrigation management in the studied area. Acquired data comprised sowing date, irrigation cessation (when plants reached physiological maturity - R6 stage), and harvest date. This information allowed us to determine the duration of irrigation management and total corn cycle (Table 1). Crop information in P1 served as a reference for obtaining data and modeling of phenological stages with NDVI, while crop information in $\mathrm{P} 2$ was used for data validation. No disorders were observed throughout the crop cycle in both areas, such as the occurrence of pests and diseases.

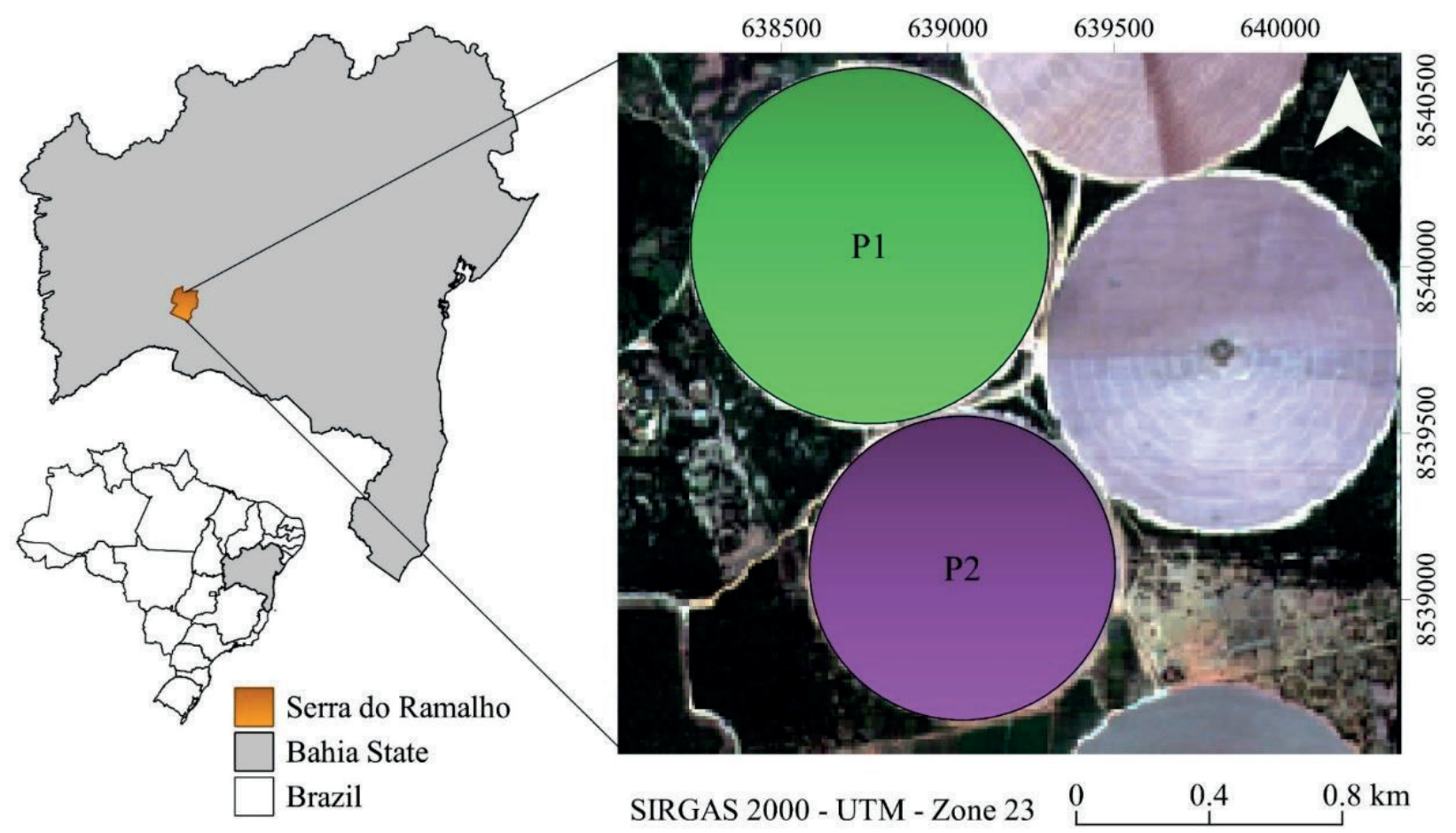

Figure 1. Location map with an emphasis of the center pivots used in the study.

\section{Table 1}

Field data for central pivots 1 (P1) and 2 (P2)

\begin{tabular}{cccccc}
\hline \multirow{2}{*}{$\begin{array}{c}\text { Central } \\
\text { pivots }\end{array}$} & \multicolumn{3}{c}{ Date } & \multicolumn{2}{c}{ Duration (days) } \\
\cline { 2 - 5 } Sowing & Irrigation suspension & Harvest & Irrigation management & Total cycle \\
\hline P1 & $05 / 05 / 2015$ & $03 / 09 / 2015$ & $25 / 09 / 2015$ & 120 & 141 \\
P2 & $12 / 05 / 2015$ & $07 / 09 / 2015$ & $30 / 09 / 2015$ & 119 & 140 \\
\hline
\end{tabular}


Meteorological data from an automatic weather station (Davis model Vantage Pro), near the study area, were acquired during irrigation management days and used to calculate reference evapotranspiration (ETo, mm day ${ }^{-1}$ ) by PenmanMonteith equation (Allen, Pereira, Raes, \& Smith, 1998). Crop evapotranspiration data (ETc, mm day ${ }^{1}$ ), estimated by modified FAO method (Bernardo, Mantovani, Silva, \& Soares, 2019; Venancio, Cunha, Mantovani, Amaral, \& Reis, 2019) and gross irrigation depth (GID, $\mathrm{mm}$ ) were also acquired for each of the central pivot areas.

\section{Orbital data}

We used the product MOD09Q1, derived from data acquired from the MODIS sensor onboard the TERRA platform, and images from the OLI sensor onboard the Landsat 8 satellite. The MOD09Q1 product contains images of surface reflectance in the red (R) and near-infrared (NIR) wavelengths, with level three processing (L3). That is, the products are spatially resampled and temporarily composed for a simple estimate of geophysical variables for each tile (location grid). This product is composed of the best pixels from daily images within an eight-day period (Justice et al., 2002; Vermote, 2015). A total of 17 images (tile H13-V10) were obtained without clouds during the crop cycle.

The OLI sensor provides eight multispectral bands (1 to 7 and 9) with 30-m spatial resolution, and band 8 (panchromatic) with a $15-\mathrm{m}$ spatial resolution (Roy et al., 2014; USGS, 2016). Landsat 8 data has a geometric correction, so images are made available orthorectified. The images have a 16-bit radiometric resolution and are available in GeoTIFF format. The geodetic reference system is a Datum WGS84 in the UTM projection (USGS, 2016). We used surface reflectance images referring to the R and NIR bands, corresponding to orbit 219 and point 69 , according to the Worldwide Reference System (WRS) for Landsat data. We selected nine cloudless images throughout the crop cycle. Both
MODIS and OLI images were obtained on the EarthExplorer platform (https://earthexplorer.usgs. gov/), from the United States Geological Survey (USGS), upon registration and authorization from the agency.

OLI sensors or MOD09Q1 products do not have a daily temporal resolution, as in this study. When using these, it could be difficult to obtain cloud-free images corresponding to sowing and harvest dates, which are essential to building vegetation index curves representative of the entire crop growth cycle. Thus, for sowing date, we used an average NDVI value for a central pivot area (average of 150 points at random) under the same conditions as those in the study areas, with sowing date corresponding to the date of image acquisition.

\section{Image processing}

Figure 2 shows and describes in detail the procedures used in this study. MODIS images were originally in sinusoidal projection and HDF format. Then, they were converted to geographic coordinates (DATUM WGS 84) and GeoTiff format, using MODIS Reprojection Tool to insert into QGIS geoprocessing software, version 3.6.1 (QGIS Development Team, 2019). In this, the images from MODIS and OLI sensors were redesigned to the Datum SIRGAS 2000 reference system, UTM coordinate system, zone $23 \mathrm{~S}$.

Thereafter, NDVI was calculated according to Equation 1 and, then, the area of interest was cut out for each image of P1 and P2. For OLI sensor images, a 30-m buffer was employed on the vector layer to extract pixel values, aiming to eliminate border effect. The extracted NDVI was the mean value of all pixels in the vector layer (Figure 3a). Yet, for MODIS images (250-m spatial resolution), NDVI was calculated from pixels fully within the area of the central pivot, as shown in Figure $3 \mathrm{~b}$. Thus, for the latter, eight points were obtained in area P1 (90 ha), and five points in P2 (66 ha). 


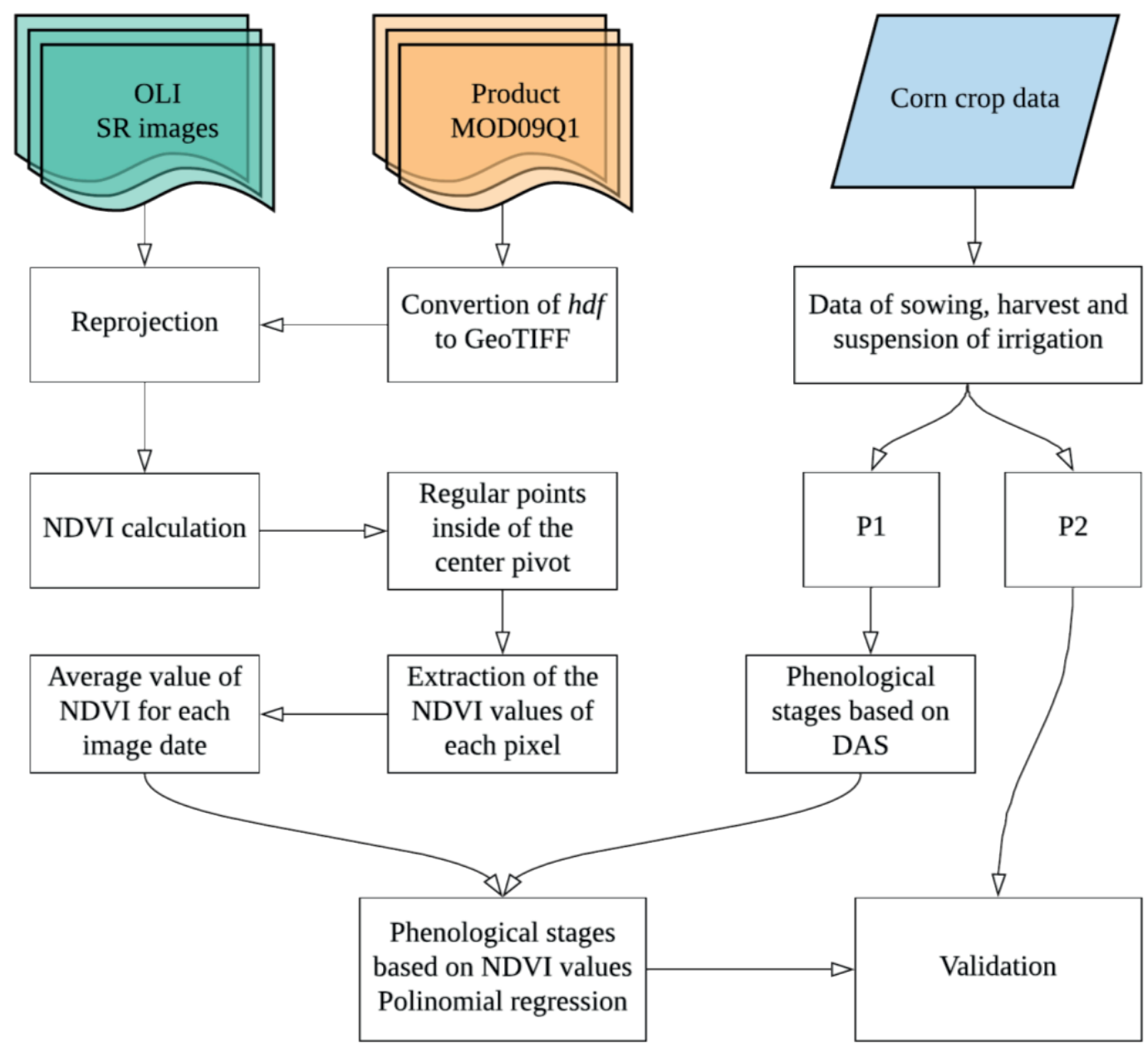

Figure 2. Procedures followed for mapping of corn phenological stages using NDVI from different orbital sensors.

a) OLI

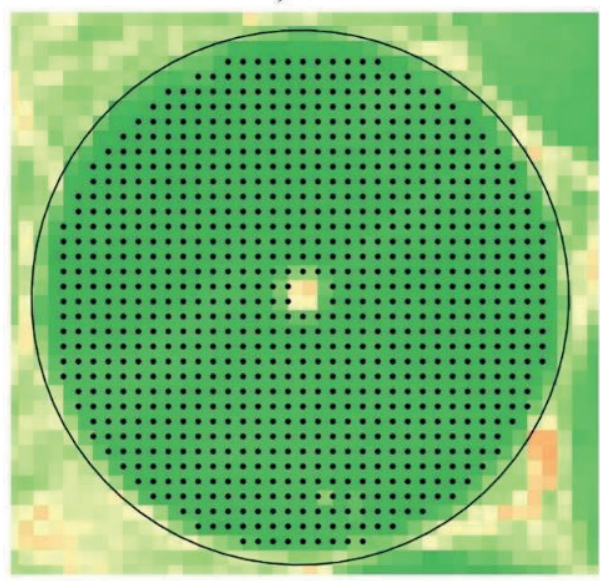

b) MODIS

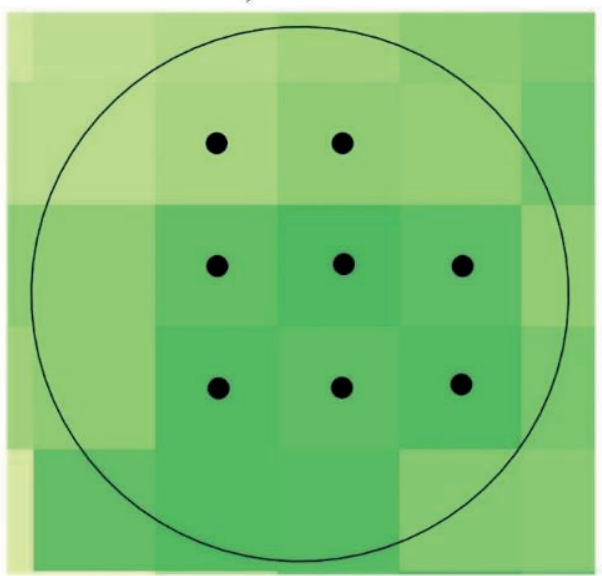

Figure 3. Schematic representation of the regular grid of points for NDVI extraction from images of OLI (a) and MODIS (b) sensors. 


$$
\mathrm{NDVI}=\frac{\rho_{\mathrm{IVP}}-\rho_{\mathrm{V}}}{\rho_{\mathrm{IVP}}+\rho_{\mathrm{V}}}
$$

Wherein: $\rho_{\mathrm{IVP}}$ is the reflectance at the near-infrared wavelength and $\rho_{\mathrm{v}}$ is the reflectance at red wavelength.

\section{Phenological stages of the corn crop}

When for grain production, corn crops have a mean total cycle of 110 to 150 days, what varies with cultivar, tillage, and climatic conditions
(Fancelli \& Dourado, 2000). In P1, 141 days passed between sowing and harvest (at 13\% moisture), while the phenological cycle from emergence (VE) to physiological maturity (R6) lasted 125 days. Within this, there are several phases important for corn management. Table 2 shows these stages and respective days after sowing (DAS) for their occurrence (Ritchie, Hanway, \& Benson, 1993). Moreover, accumulated degree-days (ADD) for planting (P1) are also presented, considering a basal temperature of $10^{\circ} \mathrm{C}$.

Table 2

Phenological stage and its respective description, and average number of days after sowing (DAS) of the main corn growth phases, as well as accumulated degree-days (ADD) for the planting of corn in the central pivot 1 (P1)

\begin{tabular}{cccc}
\hline Phenological stage & Stage description & DAS & ADD \\
\hline VE & Vegetative phase & 05 & 82 \\
V2 & Emergency & 12 & 189 \\
V4 & Two leaves fully emerged & 19 & 297 \\
V6 & Four leaves fully emerged & 408 \\
V8 & Six leaves fully emerged & 26 & 517 \\
V10 & Eight leaves fully emerged & 33 & 645 \\
V12 & Ten leaves fully emerged & 41 & 763 \\
V14 & Twoelve leaves fully emerged & 49 & 923 \\
VT & Fourtheen leaves fully emerged & 60 & 1034 \\
\hline & Tasseling & 67 & 1137 \\
R1 & Reproductive phase & 74 & 1427 \\
R2 & Silking & 94 & 1509 \\
R3 & Blister & 100 & 1673 \\
R4 & Milk & 110 & 1838 \\
R5 & Dough & 120 & 2021 \\
R6 & Dent & 130 & \\
\hline
\end{tabular}

\section{Statistical analyses}

Second-order polynomial regression was generated between NDVI values and days after sowing (DAS) for each sensor (OLI and MODIS) in P1 (reference). Afterwards, they had significance estimated through the F-test. In turn, data from P2 were used to validate those from P1. In short, they were used to prove that NDVI data range at each phenological stage can be considered as a reference for the actual corn phenology. To this end, 
the model identity test proposed by Regazzi (1993) was applied. And, the null $\left(\mathrm{H}_{0}\right)$ and alternative $\left(\mathrm{H}_{1}\right)$ hypotheses were tested by analysis of variance (ANOVA) at $5 \%$ probability $(\mathrm{p}=0.05)$, wherein:

$\mathrm{H}_{0}$ - means that equations have identical parameters $[\beta \mathrm{i}(\mathrm{P} 1)=\beta \mathrm{i}(\mathrm{P} 2)]$, so a single equation can be used for the areas;

$\mathrm{H}_{1}$ - means that equations have statistically different parameters $[\beta \mathrm{i}(\mathrm{P} 1) \neq \beta \mathrm{i}(\mathrm{P} 2)]$, so they should be used independently.

Thus, if $\mathrm{H}_{0}$ is not rejected, NDVI can be used to evaluate corn phenology since its values tend to remain similar among crops. The statistical software GENES was used for these analyses (Cruz, 2001).

\section{Results}

\section{Climatic conditions}

Figure 4 displays the data on mean air temperature, evapotranspiration, and gross irrigation depth. Over the crop cycle, air temperature averaged $25.2{ }^{\circ} \mathrm{C}$, with maximum and minimum of 27.9 and $22.5^{\circ}$ C, respectively (Figure 4a). These are close to the normal for the region, which is $25.24{ }^{\circ} \mathrm{C}$ at this time of the year (INMET, 2018).
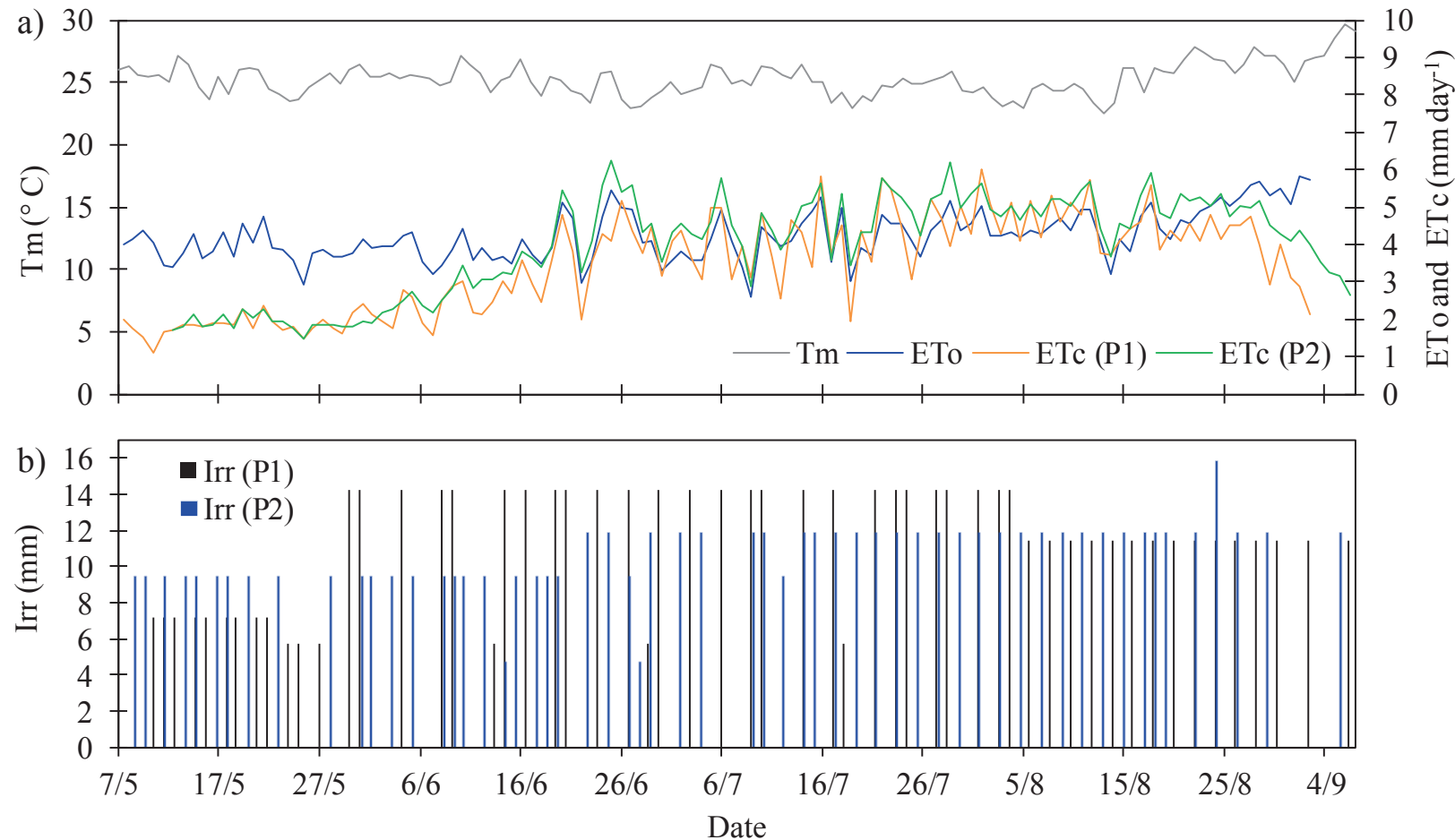

Figure 4. Average air temperature (Tm), reference evapotranspiration (ETo), crop evapotranspiration (ETc) (a), and gross irrigation depth (LB) (b) along the corn cultivation cycle for the central pivot areas P1 and P2.

ETc was similar between the two central pivot areas (Figure 4a) due to the proximity between sowing dates and similarity in tillage practices. Thus, phenological stages occurred under similar climatic conditions in both areas. Daily values of reference (ETo) and crop (ETc) evapotranspiration were more similar from June 16 to August 20 (Figure 4a), which comprises V12 and R4 in phenological terms (Table 2). Before June 16 and after August 20, ETo values were higher than ETc values (Figure $4 a)$, given the low crop evapotranspiration demand in these periods. Irrigation was constant and totaled 
56 shifts at a gross depth (GD) of $641.1 \mathrm{~mm}$ over the 120 DAS in P1. Yet, in P2, there were 58 shifts and a GD of $621.3 \mathrm{~mm}$ over 119 DAS (Figure $4 \mathrm{~b}$ ). These DG values were due to lack of rains during the corn cycle. The local climate normal shows an accumulated rainfall of only $31 \mathrm{~mm}$ between May and September (INMET, 2018), that is, low precipitation is expected for winter harvest.

\section{NDVI-based corn phenology}

Figure 5 shows that NDVI increased until 75 DAS, regardless of the sensor. This behavior is due to a biomass increase until that date, which soon after decreases; then, corn vegetative vigor is reduced along with the changing from vegetative to reproductive phase, when the lower-third leaves fall (Fancelli \& Dourado, 2000; Hanway, 1966). Moreover, OLI sensor provided a more detailed NDVI spatial variability due to its higher spatial resolution (30 $\mathrm{m}$ ) versus MODIS (250 $\mathrm{m})$. The OLI sensor also showed higher NDVI values for images at $43,75,91$, and 107 DAS, which can be verified by a darker green compared to MODIS images. Such difference can also be observed in the boxplot (Figure 5b), showing an intense photosynthetic activity of plants from vegetative phase to flowering (43 and 75 DAS), and in the initial grain-filling stage (91 DAS). This is because MOD09Q1 product images are composed of the best pixels of daily images within an eight-day period (Justice et al., 2002; Vermote, 2015), that is, the image can be composed of pixels from different acquisition dates.
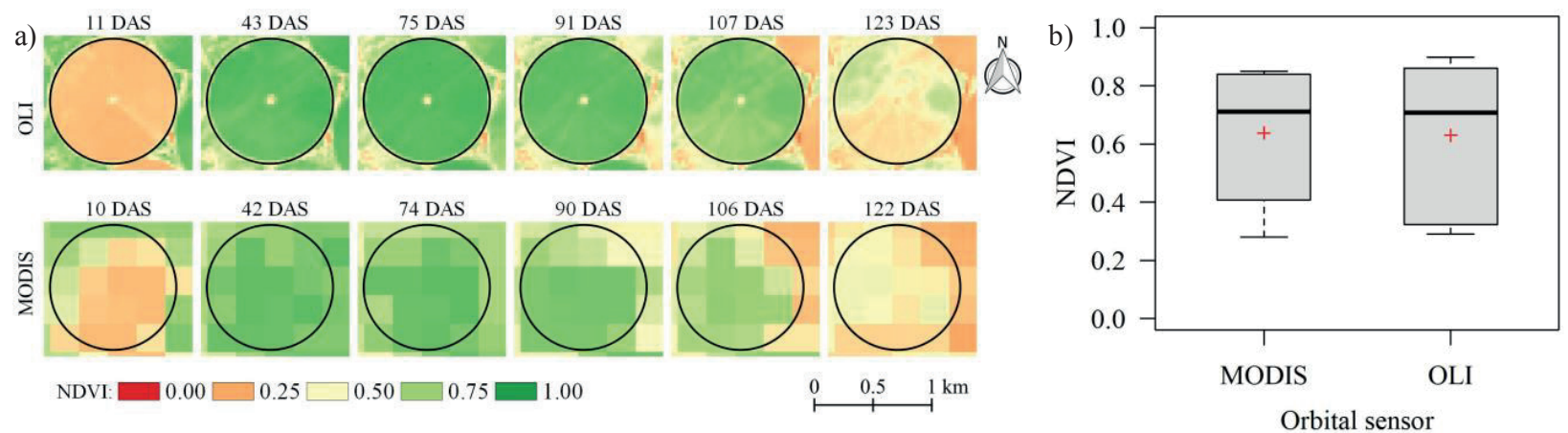

Figure 5. NDVI spatial and temporal distribution from images of OLI and MODIS sensors over the corn cropping cycle (a) and boxplot (b) for area P1. The six images that best describe the cycle were used.

Average NDVI of both sensors were very close (around 0.64), as well as the minimum value (Figure 5b). As for maximum NDVI, OLI sensor presented the largest, as previously mentioned. The boxplot with the lowest range between the 1st and 3rd quartiles for the MODIS sensor represents less data variability compared to that of the OLI sensor. Such lower variability is related to a smaller number of pixels within the pivot area provided by the low spatial resolution of this sensor. Regarding data symmetry, $50 \%$ of the values of both sensors were above 0.7 (Figure 5).
Figure 6 shows NDVI variations in images from both sensors over the entire corn cycle. For sowing date, mean NDVI was 0.29 , which coincides with the values for the harvest date. As in Figure 5, NDVI had a high sensitivity to phenological changes in vegetation, given its changes throughout the crop cycle. Therefore, it can be used to assess several crop biophysical parameters, such as crop conditions, biomass, grain yield, leaf area, and leaf nitrogen contents (Battude et al., 2016; Bertolin, Filgueiras, Venancio, \& Mantovani, 2017; Campos et al., 2018; Huang et al., 2015; Kross et 
al., 2015). Both sensors showed the largest NDVI values between 60 and 70 DAS, which correspond to tasseling (VT) and silking (R1) stages. These findings are related to a maximum leaf area index (IAF) reached close to $60 \mathrm{DAS}$, as already reported in several other studies (Bergamaschi et al., 2006; Kross et al., 2015; Soufizadeh et al., 2018). During these periods, as illustrated in Figures 5 and 6, corn plants often show the greatest vegetative vigor of their phenological cycle.

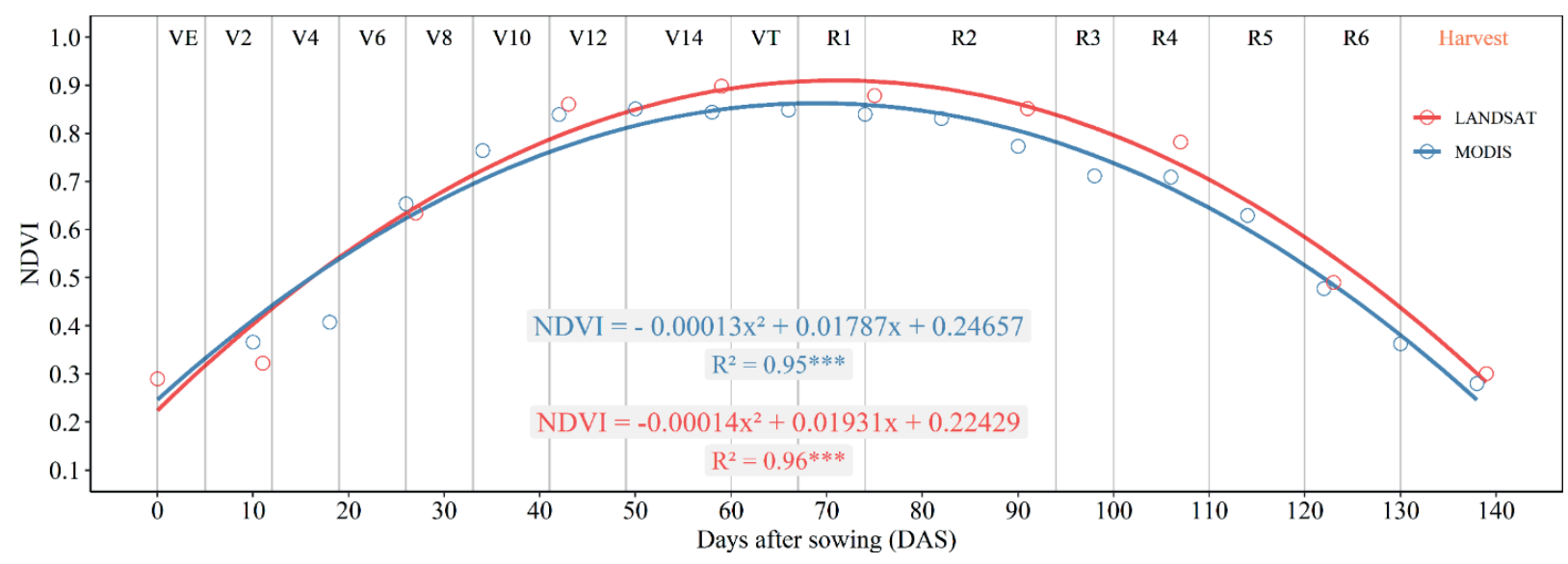

Figure 6. NDVI variation in MODIS and OLI sensor images as a function of corn phenological stage. $* * *$ significance at $0.1 \%$ probability by the F-test.

The lowest NDVI values were observed in the initial (VE to V4) and final (R5 and R6) stages. In early stages, it occurs due to low leaf area and hence low solar radiation interception. Thus, most of the incident radiation interacts with the exposed soil (or straw in no-till areas), which has high reflectance in the $\mathrm{R}$ and low in the NIR bands if compared to healthy plant (Xiao \& Moody, 2005). This fact, therefore, generates low NDVI values during that period. In the final stages, low NDVI values are due to plant senescence, which is due to reduced chlorophyll activity and translocation of accumulated photoassimilates from leaves to ears. Besides, changes in leaf architecture occur, decreasing solar radiation interception and increasing exposed soil area (Fancelli \& Dourado, 2000; Hanway, 1966).

Table 3 shows the intervals of NDVI representative of the main corn phenological stages in images from both sensors. The greatest differences between class intervals are observed in the vegetative stages $\mathrm{V} 2$ and $\mathrm{V} 4$ and reproductive stages R4, R5, and R6, with differences between initial and final values above 0.1. However, differences were minimal during tasseling (VT) and silking (R1). In short, NDVI tends to grow up to R1, from there, it starts to decrease almost linearly until it reaches lows at physiological maturity. 
Table 3

Initial and final NDVI range for the main phenological stages (vegetative and reproductive) of irrigated cornfields, calculated using images from OLI (NDVIOLI) and MODIS sensors (NDVI ${ }_{\text {MODIS }}$ )

\begin{tabular}{cccccccc}
\hline \multirow{2}{*}{$\begin{array}{c}\text { Phenological } \\
\text { stage }\end{array}$} & \multirow{2}{*}{ Stage description } & \multicolumn{2}{c}{ DAS } & \multicolumn{2}{c}{ NDVI $_{\text {OLI }}$} & \multicolumn{2}{c}{ NDVI $_{\text {MODIS }}$} \\
\cline { 3 - 8 } & & Initial & Final & Initial & Final & Initial & Final \\
\hline VE & Eegetative phase & & & & \\
V2 & Two leaves fully emerged & 5 & 12 & 0.317 & 0.436 & 0.333 & 0.442 \\
V4 & Four leaves fully emerged & 12 & 19 & 0.436 & 0.541 & 0.442 & 0.539 \\
V6 & Six leaves fully emerged & 19 & 26 & 0.541 & 0.632 & 0.539 & 0.623 \\
V8 & Eight leaves fully emerged & 26 & 33 & 0.632 & 0.709 & 0.623 & 0.695 \\
V10 & Ten leaves fully emerged & 33 & 41 & 0.709 & 0.781 & 0.695 & 0.761 \\
V12 & Twoelve leaves fully emerged & 41 & 49 & 0.781 & 0.834 & 0.761 & 0.810 \\
V14 & Fourtheen leaves fully emerged & 49 & 60 & 0.834 & 0.879 & 0.810 & 0.851 \\
VT & Tasseling & 60 & 67 & 0.879 & 0.890 & 0.851 & 0.860 \\
\hline & Reproductive phase & & & & \\
\hline R1 & Silking & 67 & 74 & 0.890 & 0.887 & 0.860 & 0.857 \\
R2 & Blister & 74 & 94 & 0.887 & 0.802 & 0.857 & 0.778 \\
R3 & Milk & 94 & 100 & 0.802 & 0.755 & 0.778 & 0.734 \\
R4 & Dough & 100 & 110 & 0.755 & 0.654 & 0.734 & 0.639 \\
R5 & Dent & 110 & 120 & 0.654 & 0.525 & 0.639 & 0.519 \\
R6 & Physiologic maturity & 120 & 130 & 0.525 & 0.369 & 0.519 & 0.373 \\
\hline
\end{tabular}

\section{Validation}

Figure 7 shows the mean NDVI results obtained directly in P2 images and those estimated by polynomial equations generated for the reference area P1 (Figure 6). For OLI sensor, greater similarities between values were obtained in the initial image (5 DAS) and later in the images of 69 and 85 DAS, when the plants still had a high vigor. In the other images, the greatest differences were found at $37 \mathrm{DAS}$, when the image value
(0.86) was 0.11 greater than the value estimated by the equation. For the MODIS sensor, the behavior was similar; however, the largest differences were observed at the beginning of the cycle (12 DAS). Although relatively high at times, these differences are always within or close to the intervals defined as standard in Table 3. This discrepancy may be due to crop management, climatic conditions in each area during the crop cycle, because, despite being close, the sowing dates were at different times (Table 1). 

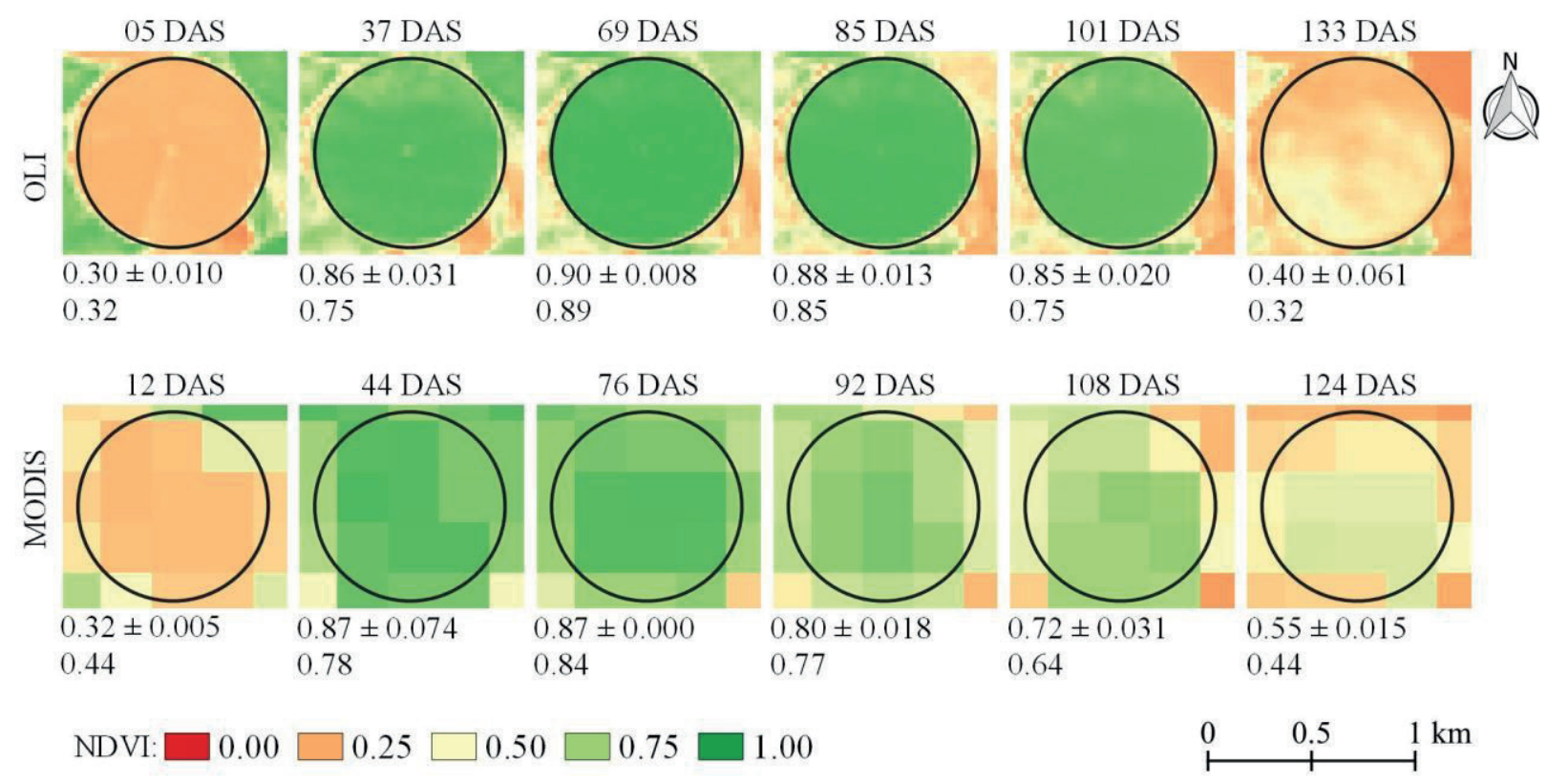

Figure 7. NDVI spatial and temporal distribution for area $\mathrm{P} 2$ and its respective mean and standard deviation for each of the six images analyzed from both OLI and MODIS sensors, together with values estimated by polynomial equations.

Table 4 presents the reduced-model ANOVA results from the model identity test. The equations of both sensors were similar since the probability (p-value) was higher than the level of significance adopted ( $\mathrm{p}<0.05)$. Thus, the null hypothesis is not rejected, that is, only one model was enough to describe NDVI changes along the corn crop cycle in both areas. Concomitantly, NDVI values in Table 4 can be used as a source of comparison to evaluate corn phenology, using NDVI from orbital images.

Table 4

Analysis of variance for the model identity test in central pivots 1 (P1) and 2 (P2)

\begin{tabular}{cccccc}
\hline SV & DF & SS & MS & F & $p$ \\
\hline \multicolumn{3}{c}{ OLI } \\
Model & 3 & 9.458646 & 3.152882 & 1135.571872 & 1.000 \\
Residual & 17 & 0.0472 & 0.002776 & & \\
Total & 20 & 9.5058 & & \\
\hline \multicolumn{2}{c}{ MODIS } & & \\
\hline Model & 3 & 16.135645 & 5.378548 & & \\
Residual & 33 & 0.0991 & 0.0991 & & \\
Total & 36 & 16.2347 & & & \\
\hline
\end{tabular}

SV: sources of variation; DF: degrees of freedom; SS: sum of squares; MS: mean square; F: calculated F-statistics; p: tabulated F-statistics. 


\section{Discussion}

In Figures 5, 6, and 7, NDVI changes can be better understood when leaf composition and structure are known in advance, as well as their respective interactions with electromagnetic radiation (EMR). Leaves have low reflectance within the visible spectrum, mainly at red and blue wavelengths. This is because solar radiation is absorbed by photosynthetic pigments in chloroplasts (chlorophylls, carotenes, and xanthophylls). But, at NIR, corn leaves have high reflectance due to their dorsiventral structure (Jensen, 2011; Ponzoni, Shimabukuro, \& Kuplich, 2012). Thus, abrupt changes in red and NIR patterns during crop growth stages lead to changes that make vegetation indices, which consider these wavelength ranges, a valuable evaluation tool for detecting crop changes (Hatfield \& Prueger, 2010).

Such NDVI dynamic-temporal behavior in cornfields has already been reported in several studies in the literature. For instance, Wardlow and Egbert (2008) evaluated NDVI in irrigated and non-irrigated corn areas in Kansas, USA. These authors observed NDVI changes NDVI over corn phenological stages, as in our study. They also found that NDVI tends to be higher in irrigated crops from the beginning of the third month of cultivation (VT stage). These higher NDVI values in irrigated areas from these stages onwards can be explained because the vegetation is often more vigorous under such condition, increasing leaf area and soil cover, thus influencing less the NDVI.

Kalfas, Xiao, Vanegas, Verma and Suyker (2011) studied NDVI from the MOD09A1 product (500$\mathrm{m}$ and 8-day resolution) of MODIS sensor between 2001 and 2005 for three areas located in Mead, Nebraska State, USA. These areas were grown with irrigated corn, irrigated corn with annual rotation with soybeans, and rainfed corn with annual rotation with soybeans. The authors observed larger NDVI values in irrigated areas and, as in our study, noted NDVI peaks near the greatest vegetative development stages, and lower values in the initial and final stages. Gitelson, Peng and Huemmrich (2014) used the product MOD 13 and noticed in a rainfed corn area, also in Mead Nebraska, NDVI ranged from 0.3 within the first weeks to its peak of 0.88 after 45 DAS. According to them, NDVI remained above 0.8 up to $75 \mathrm{DAS}$, and after that, it decreased significantly with advancing stages of maturation and senescence, corroborating our findings.

One can clearly notice that even in other countries and under other conditions of soil, climate, variety, etc., NDVI behaves dynamically and numerically in a similar manner. This undoubtedly allows us to define NDVI peaks, rises, and falls over the crop cycle, making it a powerful tool for vegetation monitoring. Yet, efficient monitoring depends on the spatial and mainly temporal resolutions of the sensor to be used. Guindin-Garcia, Gitelson, Arkebauer, Shanahan and Weiss (2012) studied green leaf area dynamics in cornfields in Nebraska (USA) using several MODIS products. These authors found that MOD09Q1 was the best product for crop monitoring due mainly to its high temporal resolution, but its disadvantage is not including information about the day on which the pixel was collected.

Despite its goodness of fit to polynomial regression, the use of NDVI from MODIS sensor (Figure 6) is usually restricted to large areas, such as the central pivot studied here, due to its low spatial resolution $(250 \mathrm{~m})$. In smaller areas, typical of family farming, it might be more appropriate to use images from sensors of higher spatial resolution, such as OLI (used here) and also Multispectral Instrument (MSI) onboard Sentinel-2A and -2B satellites, as these have a 10-m spatial resolution for the red and NIR (European Space Agency [ESA], 2015).

After being validated, the data shown in Table 3 confirm NDVI efficiency to evaluate corn phenology, becoming a major reference source through images of orbital sensors. Furthermore, NDVI availability 
brings a few benefits such as detecting variability within farming areas and estimating harvest time, which has already been shown in previous studies (Castro, Six, Plant, \& Peña, 2018; Fontana et al., 2015; Sakamoto et al., 2005).

Lastly, researchers have reported that NDVI may saturate when observing dense biomass and become insensitive to plant canopy changes from a given growth stage, that is, the index stabilizes at a plateau even if canopy density increases (Ding, Zhao, Zheng, \& Jiang, 2014; Ponzoni et al., 2012; Zanzarini, Pissarra, Brandao, \& Teixeira, 2013). In our study, NDVI might have saturated between stages V12 and R1, when it changed slightly (Figure 6). Hatfield and Prueger (2010) observed by studying several crops, among them corn, that for a long time during the cycle, NDVI values stabilize close to 0.9 , although leaf area continued to change. Likewise, Povh et al. (2008) found in corn and soybeans that NDVI reached a maximum of 0.8 and remained virtually constant, while LAI went from 2 to 6 . Thus, the joint use of other vegetation indexes should also be considered in future studies.

\section{Conclusions}

NDVI could temporarily characterize corn canopy changes over the cycle as a function of the phenological stage. The excellent polynomial fits to OLI and MODIS sensors make NDVI a worthy tool for detecting phenological changes in the corn crop. The validation of NDVI intervals for the beginning and end of each corn phenological stage was reliable, so it is a suitable parameter to access corn phenology precisely and remotely.

\section{Acknowledgements}

This study was carried out under the support of the Coordination for Improvement of Higher Education Personnel (CAPES) - Brazil, under the Financing Code No. 001, and by the National Council for Scientific and Technological Development (CNPq).
The authors would also like to thank the company IRRIGER - Gestão e Engenharia de Irrigação - for providing field data.

\section{References}

Adole, T., Dash, J., \& Atkinson, P. M. (2016). Ecological informatics a systematic review of vegetation phenology in Africa. Ecological Informatics, 34, 117-128. doi: 10.1016/j.ecoinf.2016.05.004

Allen, R. G., Pereira, L. S., Raes, D., \& Smith, M. (1998). Crop evapotranspiration: guidelines for computing crop water requirements. FAO Irrigation and Drainage Paper No. 56. Rome, Italy: Food and Agriculture Organization of the United Nations.

Alvares, C. A., Stape, J. L., Sentelhas, P. C., Moraes Gonçalves, J. L. de, \& Sparovek, G. (2013). Köppen's climate classification map for Brazil. Meteorologische Zeitschrift, 22(6), 711-728. doi: 10.1127/0941-2948/2013/0507

Atzberger, C. (2013). Advances in remote sensing of agriculture: Context description, existing operational monitoring systems and major information needs. Remote Sensing, 5(2), 949-981. doi: 10.3390/ rs5020949

Battude, M., Al Bitar, A., Morin, D., Cros, J., Huc, M., Marais Sicre, C., \& Demarez, V. (2016). Estimating maize biomass and yield over large areas using high spatial and temporal resolution Sentinel-2 like remote sensing data. Remote Sensing of Environment, 184, 668-681. doi: 10.1016/j.rse.2016.07.030

Bergamaschi, H., Dalmago, G. A., Comiran, F., Bergonci, J. I., Müller, A. G., França, S., \& Pereira, P. G. (2006). Deficit hídrico e produtividade na cultura do milho. Pesquisa Agropecuaria Brasileira, 41(2), 243-249. doi: 10.1590/S0100-204X2006000200008

Bernardo, S., Mantovani, E. C., Silva, D. D., \& Soares, A. A. (2019). Manual de irrigação. Viçosa, MG: Editora UFV.

Bertolin, N. de O., Filgueiras, R., Venancio, L. P., \& Mantovani, E. C. (2017). Predição da produtividade de milho irrigado com auxílio de imagens de satélite. Revista Brasileira de Agricultura Irrigada, 11(4), 1627-1638. doi: 10.7127/rbai.v11n400567

Borges, I. D., Von Pinho, R. G., \& Pereira, J. L. D. A. R. (2009). Acúmulo de micronutrientes em híbridos de milho em diferentes estádios de desenvolvimento. Ciência e Agrotecnologia, 33(4), 1018-1025. doi: 10.1590/S1413-70542009000400011 
Campos, I., González-Gómez, L., Villodre, J., GonzálezPiqueras, J., Suyker, A. E., \& Calera, A. (2018). Remote sensing-based crop biomass with water or light-driven crop growth models in wheat commercial fields. Field Crops Research, 216, 175188. doi: 10.1016/j.fcr.2017.11.025

Castro, A. I., Six, J., Plant, R. E., \& Peña, J. M. (2018). Mapping crop calendar events and phenology-related metrics at the parcel level by object-based image analysis (OBIA) of MODIS-NDVI time-series: a case study in central California. Remote Sensing, 10(11), 973. doi: 10.3390/rs10111745

Cross, H. Z., \& Zuber, M. S. (1972). Prediction of flowering dates in maize based on different methods of estimating thermal units 1. Agronomy Journal, 64(3), 351-355. doi: 10.2134/agronj1972. $00021962006400030029 x$

Cruz, C. D. (2001). Programa GENES - versão windows. Aplicativo computacional em genética e estatística. Viçosa, MG: Editora UFV.

Cutforth, H. W., \& Shaykewich, C. F. (1990). A temperature response function for corn development. Agricultural and Forest Meteorology, 50(3), 159171. doi: 10.1016/0168-1923(90)90051-7

Ding, Y., Zhao, K., Zheng, X., \& Jiang, T. (2014). Temporal dynamics of spatial heterogeneity over cropland quantified by time-series NDVI, near infrared and red reflectance of Landsat 8 OLI imagery. International Journal of Applied Earth Observation and Geoinformation, 30(1), 139-145. doi: 10.1016/j.jag.2014.01.009

European Space Agency (2015). SENTINEL-2 User Handbook. European Space Agency. Retrieved from https://sentinel.esa.int/documents/247904/685211/ Sentinel-2 User Handbook

Fancelli, A. L., \& Dourado, D., Neto. (2000). Produção de milho (2a ed.). Guaiba, RS: Agropecuária.

Fontana, D. C., Pinto, D. G., Junges, A. H., \& Bremm, C. (2015). Using temporal NDVI/MODIS profiles for inferences on the crop soybean calendar. Bragantia, 74(3), 350-358. doi: 10.1590/1678-4499.0439

Forsthofer, E. L., Silva, P. R. F. D., Argenta, G., Strieder, M. L., Suhre, E., \& Rambo, L. (2004). Desenvolvimento fenológico e agronômico de três híbridos de milho em três épocas de semeadura. Ciência Rural, 34(5), 1341-1348. doi: 10.1590/ S0103-84782004000500004

Gadioli, J. L., Dourado, D., Neto, García, A. G., \& Basanta, M. D. V. (2000). Temperatura do ar, rendimento de grãos de milho e caracterização fenológica associada à soma calórica. Scientia Agricola, 57(3), 377-383. doi: 10.1590/S0103-90162000000300001

Gitelson, A. A., Peng, Y., \& Huemmrich, K. F. (2014). Relationship between fraction of radiation absorbed by photosynthesizing maize and soybean canopies and NDVI from remotely sensed data taken at close range and from MODIS $250 \mathrm{~m}$ resolution data. Remote Sensing of Environment, 147, 108-120. doi: 10.1016/j.rse.2014.02.014

Guindin-Garcia, N., Gitelson, A. A., Arkebauer, T. J., Shanahan, J., \& Weiss, A. (2012). An evaluation of MODIS 8- and 16-day composite products for monitoring maize green leaf area index. Agricultural and Forest Meteorology, 161, 15-25. doi: 10.1016/j. agrformet.2012.03.012

Hanway, J. J. (1966). How a corn plant develops. How a corn plant develops. (Special Report, 38). Ames: Iowa State University of Science and Technology Cooperative Extension Service.

Hatfield, J. L., \& Prueger, J. H. (2010). Value of using different vegetative indices to quantify agricultural crop characteristics at different growth stages under varying management practices. Remote Sensing, 2(2), 562-578. doi: 10.3390/rs2020562

Huang, S., Miao, Y., Zhao, G., Yuan, F., Ma, X., Tan, C., \& Bareth, G. (2015). Satellite remote sensingbased in-season diagnosis of rice nitrogen status in Northeast China. Remote Sensing, 7(8), 1064610667. doi: 10.3390/rs70810646

Huete, A., Justice, C., \& Leeuwen, W. (1999). MODIS vegetation index (MOD 13) - Algorithm Theoretical Basis Document Version 3. Washington: National Aeronautics and Space Administration, 129 p.

Instituto Nacional de Meteorologia (2018). Normais Climatológicas do Brasil 1961-1990. Recuperado de http://www.inmet.gov.br/portal/normais_ climatologicas/mobile/index.html\#p=1

Jayawardhana, W. G. N. N., \& Chathurange, V. M. I. (2016). Extraction of agricultural phenological parameters of Sri Lanka using MODIS, NDVI time series data. Procedia Food Science, 6, 235-241. doi: 10.1016/j.profoo.2016.02.027

Jensen, J. R. (2011). Sensoriamento remoto do ambiente: uma perspectiva em recursos terrestres. São José dos Campos, SP: Parêntese.

Ji, L., \& Peters, A. J. (2007). Performance evaluation of spectral vegetation indices using a statistical sensitivity function. Remote Sensing of Environment, 106(1), 59-65. doi: 10.1016/j.rse.2006.07.010 
Justice, C. O., Townshend, J. R. G., Vermote, E. F., Masuoka, E., Wolfe, R. E., Saleous, N., \& Morisette, J. T. (2002). An overview of MODIS Land data processing and product status. Remote Sensing of Environment, 83(1-2), 3-15. doi: 10.1016/S00344257(02)00084-6

Kalfas, J. L., Xiao, X., Vanegas, D. X., Verma, S. B., \& Suyker, A. E. (2011). Modeling gross primary production of irrigated and rain-fed maize using MODIS imagery and $\mathrm{CO}_{2}$ flux tower data. Agricultural and Forest Meteorology, 151(12), 1514-1528. doi: 10.1016/j.agrformet.2011.06.007

Khanal, S., Fulton, J., \& Shearer, S. (2017). An overview of current and potential applications of thermal remote sensing in precision agriculture. Computers and Electronics in Agriculture, 139, 22-32. doi: 10.1016/j.compag.2017.05.001

Kozlowski, L. A. (2002). Período crítico de interferência das plantas daninhas na cultura do milho baseado na fenologia da cultura. Planta Daninha, 20(3), 365372. doi: 10.1590/S0100-83582002000300006

Kozlowski, L. A., Koehler, H. S., \& Pitelli, R. A. (2009). Épocas e extensões do período de convivência das plantas daninhas interferindo na produtividade da cultura do milho (Zea mays). Planta Daninha, 27(3), 481-490. doi: 10.1590/S0100-83582009000300008

Kross, A., McNairn, H., Lapen, D., Sunohara, M., \& Champagne, C. (2015). Assessment of RapidEye vegetation indices for estimation of leaf area index and biomass in corn and soybean crops. International Journal of Applied Earth Observation and Geoinformation, 34(1), 235-248. doi: 10.1016/j. jag.2014.08.002

Kuplich, T. M., Moreira, A., \& Fontana, D. C. (2013). Série temporal de índice de vegetação sobre diferentes tipologias vegetais no Rio Grande do Sul. Revista Brasileira de Engenharia Agrícola e Ambiental, 17(10), 1116-1123. doi: 10.1590/s141543662013001000014

Li, F., Miao, Y., Feng, G., Yuan, F., Yue, S., Gao, X., \& Chen, X. (2014). Improving estimation of summer maize nitrogen status with red edge-based spectral vegetation indices. Field Crops Research, 157, 111123. doi: 10.1016/j.fcr.2013.12.018

Maresma, Á., Ariza, M., Martínez, E., Lloveras, J., \& Martínez-Casasnovas, J. A. (2016). Analysis of vegetation indices to determine nitrogen application and yield prediction in maize (Zea Mays L.) from a standard uav service. Remote Sensing, 8(12), 1-15. doi: $10.3390 /$ rs8120973
Martins, K. V., Dourado- D., Neto, Reichardt, K., Favarin, J. L., Sartori, F. F., Felisberto, G., \& Mello, S. C. (2017). Maize dry matter production and macronutrient extraction model as a new approach for fertilizer rate estimation. Anais da Academia Brasileira de Ciencias, 89(1), 705-716. doi: 10.1590/0001-3765201720160525

Matsushita, B., Yang, W., Chen, J., Onda, Y., \& Qiu, G. (2007). Sensitivity of the Enhanced Vegetation Index (EVI) and Normalized Difference Vegetation Index (NDVI) to topographic effects: a case study in highdensity cypress forest. Sensors, 7, 2636-2651. doi: $10.3390 / \mathrm{s} 7112636$

Pan, Z., Huang, J., Zhou, Q., Wang, L., Cheng, Y., Zhang, H., \& Liu, J. (2015). Mapping crop phenology using NDVI time-series derived from $\mathrm{HJ}-1$ A/B data. International Journal of Applied Earth Observation and Geoinformation, 34(1), 188-197. doi: 10.1016/j. jag.2014.08.011

Ponzoni, F. J., Shimabukuro, Y. E., \& Kuplich, T. M. (2012). Sensoriamento remoto da vegetação (2a ed.). São Paulo, SP: Oficina de Textos.

Povh, F. P., Molin, J. P., Gimenez, L. M., Pauletti, V., Molin, R., \& Salvi, J. V. (2008). Comportamento do NDVI obtido por sensor ótico ativo em cereais. Pesquisa Agropecuaria Brasileira, 43(8), 10751083. doi: 10.1590/S0100-204X2008000800018

QGIS Development Team (2019). Geographic Information System (QGIS) software, version 3.6.1. Open source geospatial foundation project. Retrieved from https://qgis.org/en/site/index.html

Regazzi, A. J. (1993). Teste para se verificar a identidade de modelos de regressão e a igualdade de alguns parâmetros num modelo polinomial ortogonal. Revista Ceres, 40(228), 176-195.

Ritchie, S. W., Hanway, J. J., \& Benson, G. O. (1993). How a corn plant develops. Ames: Iowa State University of Science and Technology Cooperative Extension Service. (Special Report, 48).

Rizzard, M. A., Silva, L. F., \& Vargas, L. (2006). Controle de plantas daninhas em milho em função de quantidades de palha de nabo forrageiro. Planta Daninha, 24(2), 263-270. doi: 10.1590/S010083582006000200008

Rouse, J. W., Hass, R. H., Schell, J. A., \& Deering, D. W. (1973). Monitoring vegetation systems in the great plains with ERTS. Proceedings of the Third Earth Resources Technology Satellite-1 Symposium, Washington, D.C., USA. 
Roy, D. P., Wulder, M. A., Loveland, T. R., Woodcock, C. E., Allen, R. G., Anderson, M. C., \& Zhu, Z. (2014). Landsat-8: Science and product vision for terrestrial global change research. Remote Sensing of Environment, 145, 154-172. doi: 10.1016/j. rse.2014.02.001

Sakamoto, T., Yokozawa, M., Toritani, H., Shibayama, M., Ishitsuka, N., \& Ohno, H. (2005). A crop phenology detection method using time-series MODIS data. Remote Sensing of Environment, 96(34), 366-374. doi: 10.1016/j.rse.2005.03.008

Santos, H. G., Carvalho, W., Jr., Dart, R. de O., Áglio, M. L. D., Sousa, J. S., Pares, J. G., \& Oliveira, A. P. O. (2011). O novo mapa de solos do Brasil: legenda atualizada, escala 1:5.000.000 (1st ed.). Rio de Janeiro, RJ, Brasil: EMBRAPA Solos.

Soufizadeh, S., Munaro, E., McLean, G., Massignam, A., Van Oosterom, E. J., Chapman, S. C., \& Hammer, G. L. (2018). Modelling the nitrogen dynamics of maize crops - Enhancing the APSIM maize model. European Journal of Agronomy, 100(2016), 118131. doi: 10.1016/j.eja.2017.12.007

Tsimba, R., Edmeades, G. O., Millner, J. P., \& Kemp, P. D. (2013). The effect of planting date on maize: Phenology, thermal time durations and growth rates in a cool temperate climate. Field Crops Research, 150, 145-155. doi: 10.1016/j.fcr.2013.05.021

United States Geological Survey (2016). Landsat 8 (L8) data users handbook. Version 2.0. Department of the Interior U.S. Geological Survey, United States Geological Survey. Retrieved from https:/www. usgs.gov/land-resources/nli/landsat/landsat-8-datausers-handbook

Venancio, Cunha, Mantovani, Amaral, \& Reis. (2019). Evapotranspiração de cultura: uma abordagem dos principais métodos aplicados às pesquisas científicas e na agricultura. Irriga, 24 (3), 719-746. doi: 10.15809/irriga.2019v24n4p719-746
Vermote, E. F. (2015). MODIS surface reflectance user's guide. Collection 6. MODIS land surface reflectance science computing facility. Retrieved from https:// modisland.gsfc.nasa.gov/pdf/MOD09_ UserGuide_ v1.4.pdf

Wang, M., Tao, F. L., \& Shi, W. J. (2014). Corn yield forecasting in northeast china using remotely sensed spectral indices and crop phenology metrics. Journal of Integrative Agriculture, 13(7), 1538-1545. doi: 10.1016/S2095-3119(14)60817-0

Wardlow, B. D., \& Egbert, S. L. (2008). Large-area crop mapping using time-series MODIS $250 \mathrm{~m}$ NDVI data: an assessment for the U.S. Central Great Plains. Remote Sensing of Environment, 112(3), 1096-1116. doi: 10.1016/j.rse.2007.07.019

Xiao, J., \& Moody, A. (2005). A comparison of methods for estimating fractional green vegetation cover within a desert-to-upland transition zone in central New Mexico, USA. Remote Sensing of Environment, 98(2-3), 237-250. doi: 10.1016/j.rse.2005.07.011

Zanzarini, F. V., Pissarra, T. C. T., Brandao, F. J. C., \& Teixeira, D. D. B. (2013). Spatial correlation of the vegetation index (NDVI) of a Landsat/ETM plus images with soil attributes. Revista Brasileira de Engenharia Agricola e Ambiental, 17(6), 608-614. doi: 10.1590/S1415-43662013000600006

Zheng, Y., Wu, B., Zhang, M., \& Zeng, H. (2016). Crop phenology detection using high spatio-temporal resolution data fused from SPOT5 and MODIS products. Sensors, 16(12), 2099. doi: 10.3390/ s16122099 
